\title{
The Analysis of Ship Crews' Skill of Operating Safety Equipment in MV: Treasure Princess
}

\author{
Rachmat Tjahjanto \\ Politeknik IImu Pelayaran (PIP) Makassar
}

\author{
Iswan \\ Politeknik IImu Pelayaran (PIP) Makassar
}

\begin{abstract}
The skill of ship crews in managing emergency situation on board, which follows the required procedure of safety equipment is extremely needed and does support the process of saving people's life on the ship, in the environment, and for its load. The objective of the research is to investigate the rate of ship crews' skill in operating and lowering the lifeboat.
\end{abstract}

The research was done in MV. TREASURE PRINCESS. A company owned by PRINCESS OCEAN. The populations were twenty-one ship crews of MV. TREASURE PRINCESS. Among those numbers, seventeen people became the samples of the research. Data collecting technique used questioner and observation, while the classification of the research is quantitative research analysis.

The result of the research and data were analyzed by using liker scale to determine the rate of ship crew skill. The skill was categorized into very skillful $19 \%$, skillful $22 \%$, less skillful $37 \%$, not skillful $18 \%$, and very not skillful $4 \%$. The data used was descriptive analysis data

\section{Keywords}

crews, lifeboat lowering, SOLAS, skill

\section{INTRODUCTION}

Together with the development of technology, water transportation especially sea transportation and the demand of service users insist the sailors to increase their capability in giving the most appropriate service to the owners of the ships and the owners of the goods. The development of transportation system technology, the facility of transportation management both for goods and passengers, and the development of other infrastructure become great and significant challenges to the sailors in following the dynamics of those developments and improvements. This is not only how to operate safety equipment but also how to take the challenge in guarantying the safety of the ships, loads, and passengers when the ships are on board.

In sailing, sometimes there are some matters that can endanger the safety of all such as the danger of collision between ships, ship wreck, and the other dangers. Therefore, the crews of the ships should be able to operate safety equipments when the ships are on board. One of the causal factors that can trigger ships accidents is human error. Based on statistic data, there were $80 \%-85 \%$ accidents caused by human error (Personal Safety and Social Responsibility, Handout page 73).

When executing the duty on board, it is better that every crew puts the safety of people first as the most important factor that should get the most fundamental base. It is a must have experience because accident can happen anytime; when the ships are on board; when the ships set the anchor; when the ships load or unload their goods in the ports.

The reality that independent safety effort from an emergency situation on board has the smallest rate to be successful if the safety steps are not done with good coordination from all crews. Thus, it is significantly needed that emergency training should be done.

Related to the effort to increase the safety onboard, all crews that of course play significant role in it should have enough skill about safety on board. In the safety process, the crews should understand about how to use various safety equipment that are available on the ships. If the ships cannot be saved anymore; if all crews and passengers should leave the ships as soon as possible, all crews should take quick and appropriate response to leave the ships and to understand what actions can be done next, and to operate all safety equipment on the ships.

Based on the writer's experience in MV. Treasure Princess w when the crews got training about lifeboat including how to lower the lifeboats. Mostly they did that in 20 minutes. The calculation of the time is not relevant to SOLAS that requires 5 minutes to lower the lifeboats to the water although the ship is in $15^{\circ}$. Based on that reality, it can be known that it became the obstacle in the effectiveness of every safety effort was lack understanding about how to lower the lifeboats suitable to SOLAS standard, so the execution of safety training was less optimal.

Therefore, the writer is interested in conducting a research about the effectiveness of safety training of lifeboats by taking a research theme: The Analysis of Ship Crews' Skill of Operating Safety Equipment in MV. Treasure Princess.

\section{THE MEANING OF SKILL}

According to Mahendra, skill can refer to a particular action that is presented, or it is a character in which the skill is performed. There are a lot of activities that can be considered as skills, or it consists of several skills and degrees of achievement that can be reached by people and described the level of the skill. It can happen because it is a habit that can be accepted by general people to mention that one or several behaviors mastered by people can be called as a skill. The examples are writing, playing guitar, operating particular machines, and the other ones. If those capabilities are used, the word "skill" can be perceived as a noun. Skill can be used as an adjective although the structure changes into skillful. This word shows the rate of success in doing a particular duty or action.

By considering both aspects that have been mentioned before, it can be inferred that the term of "skill" should be defined by two ways. First, by considering the word as a noun that point sat a particular activity, people correlate it to a set of 
movement that should complete some requirements, so it can be called as a particular skill. Second, by considering as an adjective, people still relate the term of skill limited to the definition in the last context.

\section{THE MEANING OF SAFETY}

The word 'safety' is derived from the word 'safe' which means secure from accident or obstacle and secure from any disturbance. The meaning can conclude that 'safety' is the most significant factor in supporting the successfulness of ship operation, so all ship operations can un very well without any obstacle, disturbance, and disaster (http://www. anneahira. com/pengertian keselamatankerja).

However, in reality, people often see that safety is ignored by the ships crews. One of the factors that can support the safety on board is by the availability of safety equipment that can support everything in a perfect condition and ready to use. Since appropriate safety equipment on board with perfect condition can reduce the occurrence of disaster and minimize the victim if there is a bad accident on board.

To get perfect condition safety equipment, the tools on board should be maintained regularly in order to be ready in all condition and time.

\section{LEGAL LAW ABOUT SAFETY}

International Conversion about safety on board is usually called as SOLAS (Safety and Life at Sea 1974) that discusses about minimum requirement that should be filled by cargo ships and passenger ships. Legal Law number 17 year 2008 mentions the law in point 1 verse 34 about ship's safety which describes the condition of the ships with appropriate and fulfilling the requirements of material, construction, and equipment including safety equipment, radio, and ship's electricity system that can be proven by the certificate after doing some check and testing.

\section{SAFETY EQUIPMENT}

Safety equipment or life saving appliance is an equipment and complementary tool used to protect the life of ship's crews and passengers in an emergency situation on the board. The need of safety equipment is significantly needed on the board because people never know when emergency situation will come on board. According to Transportation Ministry (2000), it is mentioned that the causes of on board accident can be divided into two causes i.e. direct cause and indirect cause.

\subsection{Direct Cause}

It is a factor caused by unsafe human act, for examples:

- Less careful in doing any activities

- Do not understand how to use any particular safety equipment

- Less understanding about safety equipment

- Not capable in doing any job description

\subsection{Indirect Cause}

It is another aspect happening before the accident:

- Neglected broken part of the machine

- Ignored or not mended broken part of the machine

\section{GENERAL REQUIREMENT IN SAFETY}

There are some requirements that should be fulfilled regarding to safety equipment needed on board. They are:

a. Made from the most suitable material created by the expert

b. Should be resistant to temperature $-30^{\circ} \mathrm{C}$ until $-65^{0}$ C.

c. The color should be bright

d. Completed with the material that can reflect the light

e. Can be operated easily and well on board

f. The expired date should be clear

\section{PARTICULAR REQUIREMENT IN SAFETY}

Requirement for Lifeboat

Lifeboat safety is equipment used to evacuate the whole crews and passengers because the equipment has stronger construction and supported with the other safety equipments. One lifeboat mostly has capacity until 150 people with clear position of the seats. Some particular requirements for lifeboats are as follow:

a. Strong and good enough

b. Having big stability on the sea with big waves

c. If loaded with full capacity, there is still big floating space

d. Minimum length of the lifeboats is 4.9 meters (16 feet), and 7.3 meters (24 feet).

e. Maximum load and weight is $20.300 \mathrm{~kg}$ (20 tons) or having maximum load 150 people.

f. Completed with motor as the machine

\section{DATA COLLECTING METHOD}

The process of collecting the result of the research into a writing definitely needs a good and systematic arrangement based on the objective of the writer. Each part of the writing has a strong correlation each other. Therefore, accurate data is extremely needed. The methods used in this research are as follow:

a. Survey Method (Observation). The process is by doing a direct observation on the field in which writer tried to sail on board.

b. Interview Method. The writer had direct interview to the whole crews in order to get the real fact in the field.

c. Questioner. The questioner was given to the whole crews to get accurate data.

d. Library Research. It is a method to collect data by learning the existing data from several books that can be used as references for the research. 


\section{KINDS AND SOURCES OF THE DATA}

The data used in the research are as follow:

a. Qualitative Data. It is the data obtained in the form of variables containing rich information both from oral source and from written source. Oral source data was obtained from the interview to the sailor, the navy, and the crews. Furthermore, the data or information obtained in the form of written data was from printed source and internet.

b. Quantitative Data. It is data obtained in the form of numbers based on the data in the field that needs be processed. The data was obtained through questioner given to the crews, sailor, and navy.

Data sources that were used into the writing were:

a. Primary Data

It is data obtained directly from the source. In this case, the writer got primary data from the observation on board. Primary data can be in the form of subjects' opinion (people's opinion) either from the individual or from the group, observation result toward physical objects, occurrences or activities, and any test result.

b. Secondary Data

Secondary data is a supportive data obtained. It can be taken from other individuals doing similar research. However, it is only an additional data to support the existing data for the sake of the completeness of the research.

\section{POPULATION AND SAMPLE}

The population and the research were based on the data taken by the writer on board. The write took data from all ship's crews on board with 21 numbers of people. However, the writer set a limit by taking 17 crews as the samples.

\section{ANALYTICAL METHOD}

The research used descriptive analysis method in which writing system mostly consists description and explanation about a particular problem that appears in a particular period. The method is used to completely describe the data obtained. The main objective of the study is to give complete information about planning toward incoming problem correlated to the material discussed.

This analysis method was conducted by using several steps, as follow:

a. Taking note the number of ship's crew completely.

b. Analyzing the data of research result

c. Making conclusion based on data obtained, analyzing the data, and comparing to the result and the theory used. Based on the calculation result, the writer made a discussion related to the issue.

The variety of the research conducted on board was a quantitative research in which data obtained was in the form of numbers gotten from the research site. The data obtained still needed to be re-analyzed. The data was obtained through questioners given to the ship's crews, sailor, and navy.

\section{ANALYSIS}

During the drill training of lowering the lifeboats on MV. Treasure Princess, there were several crews who did not master and was not skillful in operating the lifeboats. It could be observed based on the time of lowering the lifeboats. Lifeboats should have been lowered in 5 (five) minutes, but during the drill the lifeboats were able to be lowered in 20 (twenty) minutes. The writer could conclude it because the writer, himself, did direct observation in the filled to investigate the level of the crews' capability in lowering the lifeboats suitable to the limitation of the problem by giving direct assessment to the crews during the training of lowering the lifeboats.

The questioner and observation data toward the skill of using safety equipments focused on lowering lifeboats. According to Jatim R \& Raharjo (1980), knowledge and skill can be categorized as follow:
a. $12<\mathrm{x} 37$
$=$ not skillful
b. $37<\mathrm{x} 68$
$=$ less skillful
c. $68<\mathrm{x} 73$
$=$ skillful enough
d. $73<\mathrm{x} 90$
$=$ skillful
e. $90<x=$ very skillful

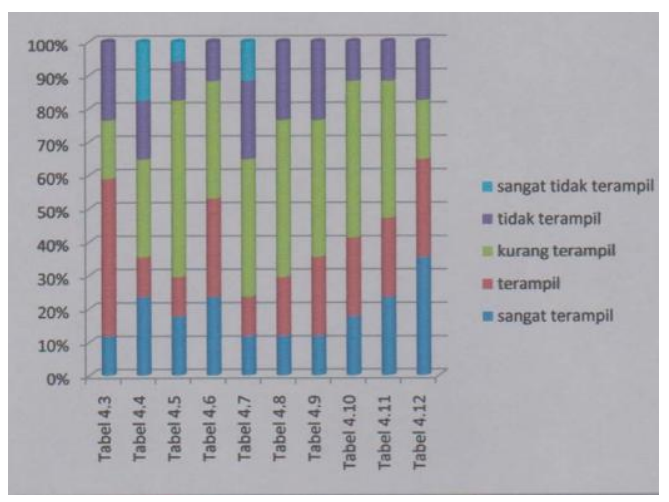

Fig 1. Questioner Result

Based on figure 1, it can be categorized that skill level of ship's crews toward lowering the lifeboat on board was in less skillful category. It means that the crews were not really skillful and capable in lowering the lifeboats, so the lifeboats were quite late to reach the surface of the water. The lifeboats should be lowered in 5 (five) minutes, but in fact the lifeboats were lowered in 10 (ten) minutes.

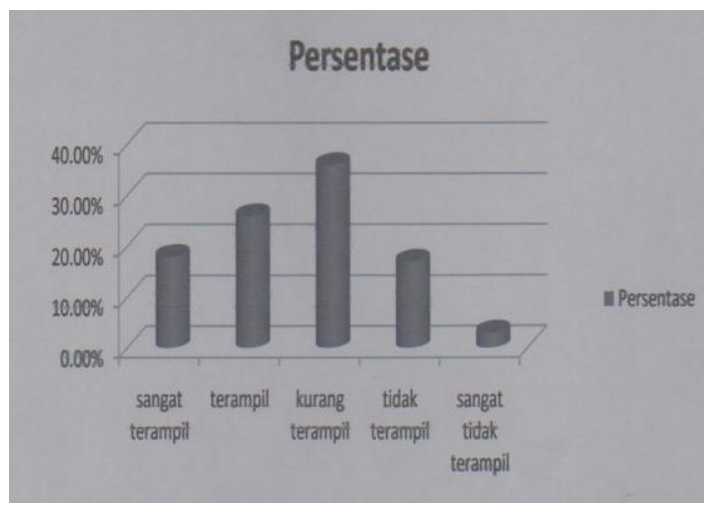

Fig 2: Recapitulation of Respondents Answer Data 
Based on the figure 2, it can be categorized that the skill of the crews in lowering the lifeboats was less skillful, so it caused the lateness of the lifeboats to reach the water surface. Based on the observation, it can be concluded that the skill and the execution in operating lifeboats in MV. Treasure Princess was still low. There were several factors causing low skill of the crews in lowering the lifeboats, as follow:

a. Less skill of the crews in operating the lifeboats because of lack drill and lack training frequency of lowering the lifeboats in every month.

b. Less maintenance of safety equipment especially equipment in the lifeboats in MV. Treasure Princess

c. The part of lifeboat training only became a formal procedure.

\section{CONCLUSION}

After doing the research, the writer can make some conclusions, as follow:

a. The rate of ship crews' skill on MV. Treasure Princess was still low. The data shows that $35 \%$ among respondents were not capable enough because of less drill or exercise in lowering the lifeboats. Thus, when the lowering process, the time was quite long. The lifeboats should be able to be lowered in 5 minutes based on the requirement of SOLAS 1974 rule 14, but during the drill and exercise lifeboats were able to be lowered in 20 minutes until reaching the water. b. Drill of exercise on lowering lifeboats only became a formal part of the training. The crews did not do it seriously during the training, so they did not completely understand and skillful in operating the lifeboats.

\section{REFERENCES}

[1] Badan Diklat Perhubungan. (2000). Personal Survival Techniques (Teknik Penyelamatan Diri), Jakarta, Departemen Perhubungan.

[2] Badan Diklat Perhubunga. ( 2000). Survival Craft And Rescue Boat, Jakarta, Departemen Perhubungan.

[3] Departemen Perhubungan Direktorat Jenderal Perhubungan Laut. (2002). SOLAS 1974, Makassar, Politeknik Ilmu Pelayaran Makassar.

[4] Jatim.R \& Raharjo.(1980) .Olah Sekoci, Semarang, Yayasan Neptunus.

[5] Soerjono. HS Capt Perlengkapan Kapal, Ujung Pandang, Yayasan Venus.

[6] Undang-Undang No. 17, 2008

[7] Tim BPLP. (1998). Penyelamatan Jiwa Manusia Di Laut, Ujung Pandang, Yayasan Venus

[8] http://www.Perlengkapan Sekoci.com

[9] http://www.Anneahira.com/PengertianKeselamatanKerja

[10] http://www.Mahendra.A,Modul 7 Keterampilan dan Domain Psikomotor (pdf) 